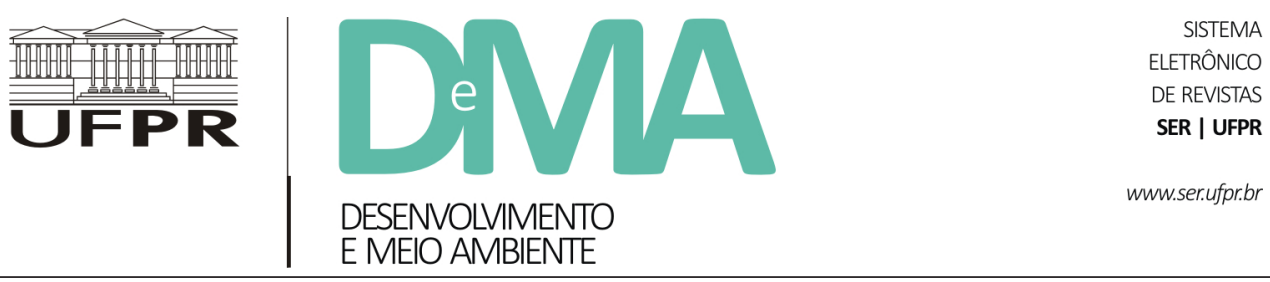

\title{
A pesca artesanal dos bagres no estuário da Lagoa dos Patos/RS: um debate sobre uma gestão pesqueira ancorada na injustiça ambiental
}

\section{The Catfish Artisanal Fishery in the Estuary of Patos Lagoon: A Debate on Fishery Management Anchored in Environmental Injustice}

\author{
Tatiana WALTER ${ }^{1 *}$, Liandra Peres CALDASSO ${ }^{2}$, Jéssica Fischer VERLY ${ }^{1}$, Ederson Pinto da SILVA ${ }^{1}$, Ivanilda \\ Foster ALMEIDA ${ }^{1}$, Tanize DIAS ${ }^{1}$ \\ ${ }^{1}$ Programa de Pós-Graduação em Gerenciamento Costeiro, Instituto de Oceanografia, Universidade Federal do Rio Grande (FURG), Rio \\ Grande, RS, Brasil. \\ ${ }^{2}$ Instituto de Ciências Econômicas, Administrativas e Contáveis (ICEAC), Universidade Federal do Rio Grande (FURG), Rio Grande, RS, Brasil. \\ *E-mail de contato: tatianawalter@furg.br
}

Artigo recebido em 31 de agosto de 2017, versão final aceita em 26 de novembro de 2017.

\begin{abstract}
RESUMO: Este trabalho aborda a problemática relacionada à proibição da pesca dos bagres no estuário da Lagoa dos Patos/RS. Considerados de grande importância para os pescadores artesanais, os bagres foram incluídos na Lista de Espécies Ameaçadas de Extinção, tendo sua captura proibida. Tal medida tem como pano de fundo uma gestão pesqueira que se reverbera injustamente sobre os pescadores artesanais, cujas tradicionalidade e reprodução social encontram-se ameaçadas. Assim, a presente pesquisa - fundamentada no debate sobre justiça ambiental - analisa os mecanismos atuais de gestão pesqueira, no Brasil e no estuário da Lagoa dos Patos, para então avaliar como a decisão estado-centrada quando da proibição da pesca artesanal do bagre ignora sua tradicionalidade, nega-lhe direitos constituídos, culminando em sua vulnerabilidade. Os procedimentos de pesquisa envolveram: i) Revisão Bibliográfica; ii) Análise Documental; iii) Entrevistas Semiestruturadas realizadas entre julho e agosto de 2016; e iv) Pesquisa Observante. Os principais resultados explicitam que os pescadores artesanais se caracterizam como comunidades tradicionais, sendo a importância do bagre associada ao fracasso de safras de outras espécies. Verificou-se que quando da elaboração da Lista não foram consultados os pescadores, nem considerados avanços já existentes no âmbito da gestão pesqueira local. A proibição tem imposto limitações na reprodução social dos pescadores, dada a multiespecificidade da pesca, em que a captura do bagre está associada a outras espécies. Neste cenário, de ocorrência de bagre nas diversas pescarias, proibir a pesca do bagre é, para os pescadores, inviabilizar sua própria existência. A ausência de diálogo por parte dos tomadores de decisão, associada à ineficácia dos mecanismos de ordenamento
\end{abstract}


pesqueiro e de regulação ambiental, culmina por responsabilizar os pescadores sobre os danos em torno do meio ambiente, desconsiderando sua dependência do mesmo. Nesse cenário, é preciso superar a dicotomia sociedade-ambiente, comumente colocada como elemento norteador da gestão pesqueira no Brasil.

Palavras-chave: gestão pesqueira; pesca artesanal; bagres; justiça ambiental; Lagoa dos Patos.

ABSTRACT: This study addresses the issues related to the catfish fishing ban in the estuary of Patos Lagoon/RS. Considered to be of great importance to artisanal fishers, the catfish were included in the list of endangered species, therefore a fishing ban was implemented. Such measure has as its background a fisheries management that reverberates unfairly on the artisanal fishers, whose traditional and social reproduction are also threatened. The present research is based on the debate about environmental justice, and analyses the current fisheries management mechanisms, in Brazil and in the estuary of Patos Lagoon, to then assess how the state centralized decision of the catfish fishing ban ignores the tradition of artisanal fisheries, denies the fishers' rights, increasing their vulnerability. The research procedures involved: i) Literature review; II) Document analysis; III) Semi-structured interviews conducted between July and August 2016; IV) Observatory research. The main results make explicit that the artisanal fishers are characterized as traditional communities, and the importance of the catfish associated with the failure in capturing other species. It was found that when the list was drawn the fishers were not consulted, and therefore the existing advances in local fisheries management were not considered. The ban has imposed limitations on the social reproduction of artisanal fishers, given the multi-specificity of their fisheries in which the capture of catfish is associated with other species. In this scenario, considering the capture of catfish in the various artisanal fisheries, the catfish fishing ban precludes the fishers from their own existence. The absence of dialogue on the part of decision makers, paired with the inefficiency of the fisheries management mechanisms and environmental regulation, hold the fishers responsible for the environmental damage, disregarding their dependency of the same environment. In this scenario, it is necessary to overcome the dichotomy society-environment, commonly placed as a guiding element of fisheries management in Brazil.

Keywords: fisheries management; artisanal fisheries; catfish; environmental justice; Patos Lagoon.

\section{Introdução}

A pesca artesanal no Brasil, realizada por comunidades tradicionais (Diegues \& Arruda, 2001), é parte da cultura do país e importante fornecedora de proteína nos municípios costeiros. A unidade produtiva é a família, envolvendo seus integrantes nos processos de captura, beneficiamento, confecção de petrechos de pesca, sendo o processo produtivo organizado pelo saber-fazer (Diegues, 1983). Sua dinâmica é influenciada pelo mercado, contudo, a lógica não é da reprodução do capital, mas da reprodução ampliada da vida (Diegues \& Arruda, 2001).
Apesar de sua relevância, nas últimas décadas a pesca artesanal convive com um processo crítico de declínio de sua produção, oriundo da degradação ambiental e da sobrepesca, resultantes de processos de ocupação desordenada, poluição e pesca predatória. Estima-se que $80 \%$ dos estoques pesqueiros de importância econômica encontram-se sobreexplotados (MMA, 2010). A despeito de um conjunto de normativas destinado à sua regulação, denominadas em seu conjunto de gestão pesqueira, mantém-se a condição de precariedade da atividade e dos pescadores e pescadoras artesanais que dela dependem (FAO, 2014). 
A pesquisa em tela possui como orientação o debate sobre a gestão pesqueira, tendo como pano de fundo a proibição da pesca de bagres marinhos das espécies Genidens barbus e Genidens planifrons, de grande importância para a pesca artesanal do estuário da Lagoa dos Patos. Tal proibição foi decorrente de sua inclusão na lista de espécies ameaçadas de extinção tanto por meio da Portaria MMA 445/2014 (IBAMA, 2014), como da Lei Estadual $\mathrm{n}^{\circ} 51.797 / 2014$ (Rio Grande do Sul, 2014), as quais listam estes bagres dentre as espécies ameaçadas no Brasil e no estado do Rio Grande do Sul. Assim, desde março de 2016 a pesca desses bagres está proibida no estado do Rio Grande do Sul.

Contudo, em nenhum momento os pescadores artesanais foram consultados, recaindo sobre os mesmos os efeitos negativos acerca da proibição. Infere-se que esta nova condição impõe limitações na reprodução social dos pescadores e pescadoras artesanais do estuário da Lagoa dos Patos (Figura 1), região com maior concentração de pescadores no estado e que tem nos bagres um dos quatro recursos de maior relevância na captura (Kalikoski \&Vasconcellos, 2013).

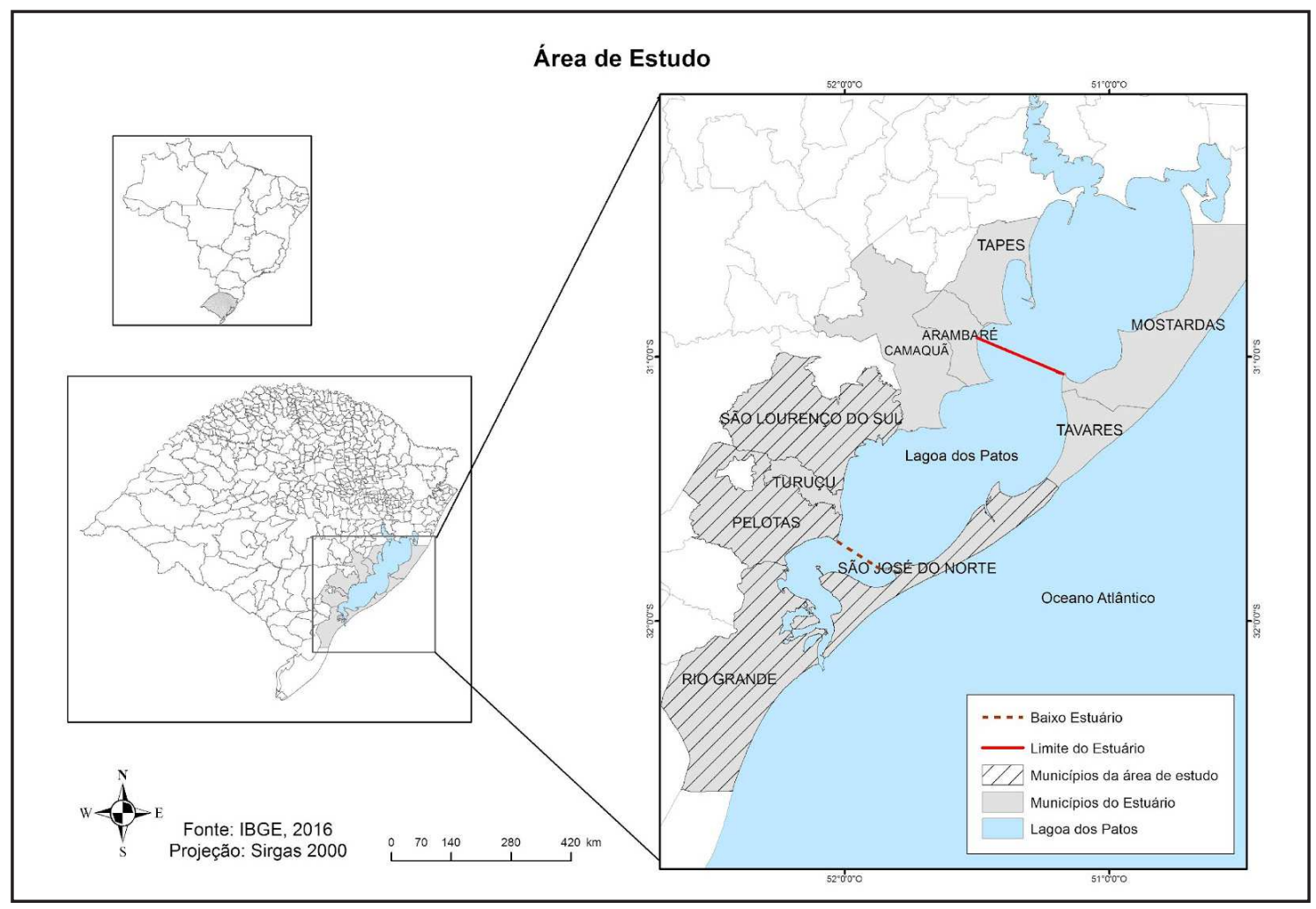

FIGURA1 - Estuário da Lagoa dos Patos, com destaque aos municípios que compõem a área de estudo. FONTE: Elaborado por Andrine Longaray. 
Ainda neste processo - que articula uma normativa nacional e outra estadual -, verifica-se que a pressão do setor industrial pesqueiro no país fez com que ocorresse, ao menos temporariamente, a suspensão da Portaria MMA 445/2015 ${ }^{1}$ devido a uma decisão judicial. Manteve-se dessa maneira a proibição da pesca dessas espécies apenas para os pescadores artesanais que atuam nas lagoas e estuários do Rio Grande do Sul, a despeito das diversas manifestações dos pescadores artesanais deste estado contra a medida ${ }^{2}$ (Fórum da Lagoa dos Patos, 2016a). Reinvindicações essas que, após rodadas de discussões junto ao Ministério Público Estadual, tiveram como encaminhamento a elaboração de um plano de manejo para os bagres que deveria ser elaborado pelos órgãos estaduais vinculados à discussão pesqueira (SEMA, 2016). No entanto, passado mais de um ano do início das discussões, até o presente momento os pescadores artesanais continuam proibidos de exercer a pesca do bagre.

Este fato revela ainda mais a arbitrariedade da decisão, dado que a indústria pesqueira, que atua sobre o mesmo recurso em alto mar, permanece possibilitada de realizar as pescarias desde que o pescado seja desembarcado em outro estado.
Assim, a presente pesquisa - fundamentada no debate sobre justiça ambiental - analisa os mecanismos atuais de gestão pesqueira para então avaliar como a decisão estado-centrada de proibição da captura dos bagres, imposta aos pescadores artesanais do estuário da Lagoa dos Patos, ignora sua tradicionalidade e nega-lhe direitos constituídos, culminando em sua vulnerabilidade.

\subsection{A concepção da pesquisa como ação}

A pesquisa em tela tem como referência a atuação de parte de seus autores, enquanto integrantes da universidade, junto ao Fórum da Lagoa dos Patos $^{3}$. A participação nesta instância data do início de 2015 de forma recorrente. Em síntese, os autores estão envolvidos em sua rotina, como na participação em reuniões e nos diálogos com as lideranças pesqueiras que coordenam o Fórum, no planejamento e na realização de suas reuniões. Também atuam na assessoria técnica relacionada às questões ambientais, conforme demandas dos próprios pescadores.

Quando da constatação de proibição da pesca artesanal do bagre, em fevereiro de 2016 (Fórum da

\footnotetext{
${ }^{1}$ A decisão judicial foi motivada pelo setor pesqueiro, tendo sido a portaria 445/2015 suspensa por mais de uma vez, conforme notícia veiculada em 02.09.2016 pelo Jornal $O$ Estadão: <http://ciencia.estadao.com.br/blogs/herton-escobar/lista-de-peixes-ameacados-de-extincao-e-suspensa-de-novo/>. Acesso em: 18 nov. 2017.

${ }^{2}$ A notícia veiculada em 29.03.2016 no Diário Gaúcho exemplifica alguns dos efeitos da proibição da pesca artesanal sobre os pescadores artesanais no Rio Grande do Sul e como ocorreu o processo de inclusão das espécies de peixe na Lista Vermelha da IUCN que culminou na proibição da pesca do bagre. Disponível em: <http://diariogaucho.clicrbs.com.br/rs/dia-a-dia/noticia/2016/03/lei-proibe-a-pesca-de-bagre-no-estado-5526538.html>. Acesso em 18 nov. 2017.

${ }^{3}$ O Fórum da Lagoa dos Patos foi criado em 1996 devido à crise pesqueira vivenciada no estuário da Lagoa dos Patos/RS na década de 1990. É parte do conjunto de experiências protagonizadas pelo IBAMA denominadas de Gestão Participativa e que foram delineadas pelo órgão devido à necessidade de maiores diálogos e envolvimento do setor na proposição de medidas destinadas à gestão sustentável do uso dos recursos pesqueiros e está situado no bojo de experiências de participação no período de redemocratização do país. Realiza reuniões ordinárias mensais em quatro de seus cinco municípios de abrangência: Rio Grande, São José do Norte, Pelotas, São Lourenço do Sul e Tavares. Atualmente, envolve a participação dos representantes dos pescadores artesanais, prefeituras, órgãos federais e estaduais que atuam no fomento e na conservação dos recursos pesqueiros, Universidades, Organizações NãoGovernamentais, dentre outros.
} 
Lagoa dos Patos, 2016c), foi iniciada uma mobilização pelos pescadores, que solicitaram aos autores uma pesquisa acerca dos impactos da proibição da captura do bagre sobre os seus modos de vida, o que foi estabelecido como um compromisso da própria universidade (Fórum da Lagoa dos Patos, 2016c).

Assim, o objetivo de compreender os regramentos previstos e os impactos destes no cotidiano da pesca artesanal no estuário da Lagoa dos Patos foi traçado conjuntamente com os pescadores, que definiram como questão orientadora a compreensão dos efeitos da medida sobre o exercício da pesca e na produção pesqueira. Um segundo questionamento era o fato de o Fórum não ter participado de nenhum debate pretérito, apesar de sua existência desde 1996 (Fórum da Lagoa dos Patos, 2016c).

Para Freitas (2004),

Metodologias participativas como forma de fortalecer os laços comunitários de solidariedade devem estar orientadas para o incremento do poder técnico e político das comunidades nos processos decisórios que afetam o nível local, reafirmando de forma radical a democracia nas relações sociais, políticas, econômicas e culturais, elementos fundamentais para sustentabilidade e justiça ambiental. (Freitas, 2004, p. 151).

Associada à pesquisa-ação - método científico que tem como referência a construção dos objetivos da pesquisa por seus sujeitos e o compromisso com a transformação de sua realidade (Thiollent, 2007) -, foi definida uma série de procedimentos ancorados na pesquisa social qualitativa. Assim, utilizou-se de pesquisa documental, revisão bibliográfica, entrevistas semi-estruturadas e pesquisa observante para compor o quadro analítico, conforme descrito em Minayo (2013).
A pesquisa documental ocorreu sobre dois principais acervos: a legislação pertinente nos níveis federal e estadual e as atas referentes às Reuniões Ordinárias e Extraordinárias do Fórum da Lagoa dos Patos, no período de 2015 a 2017, disponíveis no sítio http://www.forumlagoadospatos.furg.br. O acervo contempla as atas desde sua criação, em 1996, sendo que eventualmente foram pesquisados documentos referentes a outros períodos.

A revisão bibliográfica é aquela que fundamenta teoricamente a pesquisa, assim como faz uso de estudos científicos pretéritos sobre a pesca artesanal na Lagoa dos Patos, necessários à triangulação de métodos e de resultados (Minayo et al., 2005). Este procedimento, comum a pesquisas sociais qualitativas, visa à triangulação de informações e de métodos de forma a evitar inconsistências na análise dos resultados. Ou seja, a triangulação é realizada com vistas a estabelecer o rigor metodológico necessário à análise da dinâmica social, diferenciando uma pesquisa sociológica de uma análise sobre a opinião dos sujeitos investigados (Minayo et al., 2005).

$\mathrm{O}$ terceiro procedimento ocorreu por meio de entrevistas semiestruturadas. Dadas as características da pesca artesanal, cuja dinâmica articula diferentes estratégias com vistas à captura e à comercialização do pescado, optou-se por elaborar um roteiro que a contemplasse de forma ampla. No período de julho a agosto de 2016 , foram realizadas entrevistas junto aos pescadores artesanais de São Lourenço do Sul (18 entrevistados), Pelotas (19 entrevistados), Rio Grande (17 entrevistados) e São José do Norte (14 entrevistados). Para cada entrevista, conduzida por dois pesquisadores, foi assinado termo de concessão de entrevista. Além de um pesquisador conduzir e o outro ficar responsável pelo registro, as entrevistas foram gravadas. Pos- 
teriormente, as informações foram categorizadas, para possibilitar as análises.

$\mathrm{O}$ quarto procedimento relaciona-se à participação dos pesquisadores nas reuniões junto ao Fórum da Lagoa dos Patos; ao Ministério Público; à Secretaria do Ambiente e do Desenvolvimento Sustentável do Rio Grande do Sul - SEMA - e ao Conselho Gaúcho de Aquicultura e Pesca Sustentáveis do Rio Grande do Sul - CONGAPES. Todos estes entes atuaram sobre a proibição do bagre no período.

Denominada de observação participante, esta técnica é "um processo pelo qual se mantém a presença do observador numa situação social, com a finalidade de realizar uma investigação científica" (Minayo, 2013, p. 273). Este pode atuar apenas como observador ou ser parte do processo de negociação, atuando ativamente. Tal técnica demanda uma série de cuidados, dentre os quais a relativização social por parte do pesquisador, o registro sistemático das informações em cadernos de campo, dentre outros descritos na literatura sobre pesquisa social qualitativa.

Após sistematização, os resultados foram apresentados aos pescadores artesanais na Reunião Ordinária do Fórum da Lagoa dos Patos em 29/09/2016, na Colônia Z-01 em Rio Grande (Fórum da Lagoa dos Patos, 2016d). O objetivo foi estabelecer um diálogo com as comunidades e validar os resultados obtidos. Também é relevante destacar, que no período de maio de 2016, quando a universidade assumiu junto aos pescadores a proposição desta pesquisa, até a reunião de setembro, todas as reuniões trataram da pesca artesanal do bagre e, em todas elas, os autores expuseram aos participantes o andamento da pesquisa, integrando-os ao processo. Algumas das falas no próprio Fórum foram consideradas para triangulação dos resultados.

\section{Justiça ambiental e tradicionalidade como elementos norteadores da pesquisa}

O conceito sobre Justiça Ambiental surgiu na década de 1980 nos Estados Unidos, quando movimentos sociais constataram que a localização dos aterros de resíduos tóxicos industriais nada tinha de aleatória. Em sua maior parte, estava situada em bairros pobres de comunidades negras. A outra parte, em bairros latino-americanos, deflagrando uma intencionalidade em destinar o ônus do desenvolvimento a etnias específicas, o que então foi denominado de Racismo Ambiental. Para combater tal prática, surge o Movimento por Justiça Ambiental (Herculano, 2008).

Em 2000, este debate tem início no Brasil e articula movimentos sociais e pesquisadores que observam que as desigualdades em torno do acesso ao meio ambiente se sobrepõem aos mecanismos de desigualdades sociais no país, obscurecendo-as e dissimulando-as, fazendo-se necessário ampliar este debate para outros grupos sociais (Acselrad, 2004).

A partir desta constatação, ocorre um esforço teórico no campo da Sociologia Ambiental em compreender, por meio das hierarquias sociais e desigualdades de classe, a problemática ambiental (Herculano, 2008). Para Martínez Alier (2011), Justiça Ambiental, Ecologismo dos Pobres e Ecologia Política constituem-se o campo do conhecimento cujo esforço está em compreender aspectos distributivos do meio ambiente, explicitando os mecanismos institucionais e de mercado que contribuem para este processo. 
Na perspectiva da Ecologia Política, a busca pela superação da crise ambiental envolve compreender que esta se refere a uma questão de base material, pois não é apenas uma visão de mundo que precisa ser mudada, mas também as relações sociais que têm como pano de fundo a interação com o acesso (livre ou regulado), a apropriação (individual ou coletiva) e o uso (privado ou público) dos recursos ambientais (Layrargues, 2009).

Logo, na concepção da Ecologia Política, a construção da sustentabilidade envolve fortemente o estabelecimento de políticas ambientais que criem regras de convívio social reguladoras do acesso e do uso dos recursos ambientais, definindo os critérios para a repartição dos benefícios e prejuízos das riquezas geradas pelo uso dos produtos e serviços ambientais, bem como dos benefícios e prejuízos dos efeitos das políticas ambientais. Sendo assim, a política ambiental, quando formulada intencionalmente com o compromisso de combater a injustiça ambiental, emerge potencialmente como uma questão de justiça distributiva, contribuindo com o enfrentamento da dimensão ambiental da desigualdade (Layrargues, 2009).

O que está posto no debate pela Ecologia Política não é a escassez dos recursos ambientais, havendo consenso sobre tal. Mas, sim, a necessidade de se pensar eticamente sobre a finalidade de tais recursos que são escassos (Acselrad, 2004). Este debate encontra-se imbricado à relação Sociedade \& Ambiente e se estabelece no compromisso junto aos grupos mais vulneráveis às decisões em torno do meio ambiente.

Conceitualmente, Justiça Ambiental tem como fito o tratamento justo e o envolvimento significativo de todas as pessoas, independentemente de sua raça, cor, origem ou renda, no que diz respeito à elaboração, ao desenvolvimento, à implementação e aos reforços de políticas, leis e regulações ambientais (Acselrad, 2004).

Herculano (2008), coloca que,

Por tratamento justo entende-se que nenhum grupo de pessoas, incluindo-se aí grupos étnicos, raciais ou de classe, deva suportar uma parcela desproporcional das consequências ambientais negativas, resultantes de operações industriais, comerciais e municipais, da execução de políticas e programas federais, estaduais, locais ou tribais, bem como das consequências resultantes da ausência ou omissão dessas políticas (Herculano, 2008, p.2).

Ainda para Herculano (2008, p.7), alguns fatores ideológicos têm contribuído para dificultar a percepção sobre a injustiça ambiental, dentre os quais está "o conservacionismo de uma corrente do movimento ambientalista que ignora as questões do universo da produção e que acredita que os problemas ambientais são democráticos por atingirem a todos, o que só é verdade em longo prazo quando, como lembrou Keynes, todos estaremos mortos".

Alguns dos princípios que são defendidos no campo da justiça ambiental versam sobre: i) o acesso justo e equitativo, direto e indireto, sobre os recursos ambientais do país; ii) amplo acesso às informações relevantes sobre o uso dos recursos ambientais e a destinação dos rejeitos assegurado por meio de processos participativos e democráticos na definição das políticas, planos, programas e projetos que lhe dizem respeito; e iii) o favorecimento e a constituição de sujeitos coletivos e de direitos, movimentos sociais e organizações populares, a protagonizarem outras formas de vida, outros modos de desenvolvimento, ou seja, outra racionalidade 
na relação com o ambiente (Herculano, 2008, p. 11 e 12).

No campo teórico e com vistas a dar sustentação sobre os direitos dos pescadores artesanais em relação ao ambiente e ao seu território, faz-se necessário conceituar populações tradicionais e situar como as normativas que visam ao atendimento das necessidades básicas para a sua produção e reprodução social se articulam com a questão da justiça ambiental.

No Brasil, a Constituição Federal de 1988 estabelece em seu Art. 225, o meio ambiente ecologicamente equilibrado como um direito de todos e "bem de uso comum do povo e essencial à sadia qualidade de vida, impondo-se ao Poder Público e à coletividade o dever de defendê-lo e preservá-lo para as presentes e futuras gerações" (Brasil, 1988). Ou seja, todo e qualquer cidadão tem direito ao meio ambiente equilibrado, incluindo-se então as comunidades tradicionais, que, além de socioculturalmente diferenciadas, se caracterizam principalmente por uma relação intrínseca às condições naturais do ambiente.

As comunidades tradicionais têm seus direitos assegurados também por normas e políticas específicas em diversos níveis, tanto nacionais quanto internacionais. Dentre as normas internacionais, há a Convenção $n^{\circ} 169$ - Sobre Povos Indígenas e Tribais, da Organização Internacional do Trabalho (OIT), ou OIT 169, da qual o Brasil é signatário, internalizada no país por meio do Decreto 5.051/2004 (Brasil, 2004). Essa convenção aplica-se aos povos considerados tradicionais, como:

a) aos povos tribais em países independentes, cujas condições sociais, culturais e econômicas os distingam de outros setores da coletividade nacional, e que estejam regidos, total ou parcialmente, por seus próprios costumes ou tradições ou por legislação especial; b) aos povos em países independentes, considerados indígenas pelo fato de descenderem de populações que habitavam o país ou uma região geográfica pertencente ao país na época da conquista ou da colonização ou do estabelecimento das atuais fronteiras estatais e que, seja qual for sua situação jurídica, conservam todas as suas próprias instituições sociais, econômicas, culturais e políticas, ou parte delas (Brasil, 2004).

Em seu Artigo $4^{\circ}$, o Decreto 5.051/2004, determina que "1. Deverão ser adotadas as medidas especiais que sejam necessárias para salvaguardar as pessoas, as instituições, os bens, as culturas e o meio ambiente dos povos interessados", e que "2. Tais medidas especiais não deverão ser contrárias aos desejos expressos livremente pelos povos interessados" (Brasil, 2004).

Nesse contexto, o Brasil, por meio do Decreto 6.040, de 7 de fevereiro de 2007 (Brasil, 2007), instituiu a Política Nacional de Desenvolvimento Sustentável dos Povos e Comunidades Tradicionais (PNPCT), que, conforme seu Artigo $3^{\circ}$, compreende por Povos e Comunidades Tradicionais como:

Grupos culturalmente diferenciados e que se reconhecem como tais, que possuem formas próprias de organização social, que ocupam e usam territórios e recursos naturais como condição para sua reprodução cultural, social, religiosa, ancestral e econômica, utilizando conhecimentos, inovações e práticas gerados e transmitidos pela tradição (Brasil, 2007).

Dentre os objetivos da PNPCT, cabe destacar: "I - garantir aos povos e comunidades tradicionais seus territórios e o acesso aos recursos naturais 
que tradicionalmente utilizam para sua reprodução física, cultural e econômica" (Brasil, 2007). Ademais, em seu Artigo $1^{\circ}$, a PNPCT estabelece que ações e atividades voltadas para o alcance dos seus objetivos deverão ocorrer de forma intersetorial, integrada, coordenada, sistemática e observando, dentre outros, os seguintes princípios:

[...] V- o desenvolvimento sustentável como promoção da melhoria da qualidade de vida dos povos e comunidades tradicionais nas gerações atuais, garantindo as mesmas possibilidades para as gerações futuras e respeitando os seus modos de vida e as suas tradições; [...] IX - a articulação com as demais políticas públicas relacionadas aos direitos dos Povos e Comunidades Tradicionais nas diferentes esferas de governo; $\mathrm{X}$ - a promoção dos meios necessários para a efetiva participação dos Povos e Comunidades Tradicionais nas instâncias de controle social e nos processos decisórios relacionados aos seus direitos e interesses (Brasil, 2007).

Destaca-se, ainda, sobre participação nas políticas públicas, que a própria Política Nacional de Desenvolvimento Sustentável dos Povos e Comunidades Tradicionais estabelece enquanto instrumentos, dentre outros, "os fóruns regionais e locais" como instâncias de participação social das comunidades tradicionais. No estuário da Lagoa dos Patos, tal proposição remete à atuação do Fórum da Lagoa dos Patos, que desde 1996 atua na gestão dos recursos pesqueiros (Fórum da Lagoa dos Patos, 1998).

Ademais, conforme o Artigo $7^{\circ}$ do Decreto $5.051 / 2004$, "os governos deverão adotar medidas em cooperação com os povos interessados para proteger e preservar o meio ambiente dos territórios que eles habitam", e, em seu Artigo 23, o Decreto5.051/2004 determina que:

[...] atividades tradicionais e relacionadas com a economia de subsistência dos povos interessados, tais como a caça, a pesca com armadilhas e a colheita, deverão ser reconhecidas como fatores importantes da manutenção de sua cultura e da sua autossuficiência e desenvolvimento econômico. Com a participação desses povos, e sempre que for adequado, os governos deverão zelar para que sejam fortalecidas e fomentadas essas atividades (Brasil, 2004, grifo nosso).

Não obstante, é importante destacar que diversos autores (Diegues, 1983; Arruda, 1989; Diegues \& Arruda, 2001; Leff, 2006; Porto-Gonçalves \& Leff, 2015) enfatizam a relação dialética e/ou de coevolução entre as sociedades tradicionais e o meio ambiente, assim como a potencial conservação do ambiente em territórios habitados por tais populações, distanciando-se de correntes conservacionistas que perpetuam a ideia do "culto ao silvestre". Em consequência, há necessidade de políticas públicas que dialoguem com tais comunidades, garantindo seus direitos ao ambiente, bem como a conservação do mesmo. Em outras palavras, que assegurem o direito aos sujeitos coletivos de organizarem seu modo de vida e protagonizarem outros modelos de sociedade, bem como de manutenção de outra relação sociedade-ambiente.

\subsection{A tradicionalidade da pesca artesanal}

A discussão teórica acerca da tradicionalidade da pesca artesanal torna-se especialmente importante pelo fato de esta possuir algumas particula- 
ridades que se referem à compreensão do modo de vida, baseado no conhecimento tradicional e na relação com o meio físico natural. Diferentemente das populações indígenas e quilombolas, os pescadores artesanais não possuem um dispositivo constitucional que assegure o acesso ao território, fragilizando-os ainda mais - em comparação a estes grupos - quando de decisões em torno do meio ambiente. Assim, a despeito do Decreto Federal $\mathrm{n}^{\circ}$ 6.040 de 2007 (Brasil, 2007), que institui os territórios tradicionais, não há ainda mecanismos legais e institucionais que culminem em seu reconhecimento aos pescadores artesanais.

Para além de uma atividade produtiva, a pesca artesanal também se destaca enquanto patrimônio cultural e histórico, sendo a perpetuação da atividade baseada em conhecimentos (segredos da profissão) passados de geração em geração e que contribuem para o reconhecimento dos pescadores artesanais enquanto populações tradicionais (Diegues, 1983; Silva, 1988; Diegues \&Arruda, 2001).

A pesca artesanal pode ser compreendida a partir de sua forte dependência do ambiente, uma vez que extrai dele o seu produto e, como destaca Diegues (1983, p. 95), "em sociedades que vivem da exploração direta da natureza (baseadas na agricultura, pesca etc.) há uma correlação importante entre a reprodução social e a reprodução natural".

$\mathrm{O}$ "saber-fazer", que se refere aos conhecimentos dos pescadores artesanais em torno dos aspectos necessários ao desenvolvimento da atividade pesqueira, é constitutivo da profissão, e que, em conjunto com uma série de qualidades físicas e intelectuais, permite o domínio sobre as artes de pesca (Diegues, 1983). Comunidades pesqueiras artesanais possuem características de "sociedades tradicionais", estas entendidas como "grupos humanos diferenciados sob o ponto de vista cultural, que reproduzem historicamente seu modo de vida, de forma mais ou menos isolada, com base na cooperação social e em relações próprias com a natureza" (Diegues \& Arruda, 2001, p. 20).

\section{Tradicionalidade da pesca artesanal no estuário da Lagoa dos Patos}

A pesca artesanal desenvolvida no estuário da Lagoa dos Patos tem sua produção baseada na unidade familiar e as principais espécies capturadas são: camarão, corvina, tainha, bagre e linguado. Outras espécies, como peixe-rei, siri, jundiá, viola e traíra, também são capturadas, em menores quantidades. Tais dados foram declarados pelos pescadores artesanais entrevistados e vão ao encontro de dados elencados por Kalikoski \& Vasconcellos (2013) e dos dados publicados no Boletim Estatistico da Pesca Marinha e Estuarina do Sul do Rio Grande do Sul, realizado pela Universidade Federal do Rio Grande - FURG (FURG, 2012; 2013a; 2013b; 2014; 2015; 2016).

De acordo com os dados do Registro Geral de Pesca (RGP), no ano de 2012, na área de pesquisa totalizavam-se 6.810 pescadores artesanais, distribuídos da seguinte forma: 2.685 em São José do Norte, 2.398 em Rio Grande, 1.326 em Pelotas e 401 em São Lourenço do $\mathrm{Sul}^{4}$. Os pescadores em geral são os próprios donos de seus meios de produção,

\footnotetext{
${ }^{4}$ Informações retiradas do site <http://www.trabalhocompescadores.furg.br>, que apresenta uma sistematização sobre a cadeia produtiva da pesca artesanal no estado do Rio Grande do Sul. Segundo o arquivo, os dados foram obtidos por meio da consulta ao Registro Geral de Pesca do Ministério da Pesca e Aquicultura no ano de 2012.
} 
ou seja, das embarcações e petrechos de pesca, e trabalham com familiares (pai, irmãos, tios, filhos, esposa), assim como com a vizinhança. Nos casos em que não possuem embarcação própria, trabalham como tripulantes de embarcação de familiares ou vizinhos, levando suas redes para a pescaria, ou apenas participando com sua força de trabalho.

Em relação às embarcações utilizadas na atividade pesqueira artesanal no estuário da Lagoa dos Patos, Kalikoski \& Vasconcellos (2013) destacam:

Características comuns dos barcos pesqueiros artesanais são que todos são construídos com pranchas de madeira, sem qualquer cabine permanente (tendas e convés removíveis costumam ser usados), convés ou compartimento para o pescado. Os barcos motorizados [...] têm um casco em forma de "v", levam um motor de centro e usam diesel (mais comum), gasolina ou gás (menos comum) como combustível. [...] Os pescadores normalmente têm um barco auxiliar (normalmente sem motor), chamado "caíco" ou "batera", também construído com pranchas de madeira, mas com um fundo chato. Esses barcos variam de tamanho de 1.5 a 5.5 metros e são usados em pescarias em águas rasas (como nas pescarias de camarão com aviãozinho), no carregamento das redes e no transporte do pescado e pescadores (Kalikoski \&Vasconcellos, 2013, p.22).

Nos quatro municípios pesquisados, há um total de 2.424 embarcações pesqueiras artesanais, entre caícos e barcos motorizados (Kalikoski \&Vasconcellos, 2013).

Com unidade de produção comumente familiar, o envolvimento de familiares se dá em diversas etapas da atividade pesqueira, seja na captura na lagoa, seja em terra por meio da manutenção de petrechos, beneficiamento do pescado e/ou comercialização. Tais papéis em terra são assumidos principalmente pelas mulheres, junto aos afazeres domésticos e ao cuidado dos filhos. Todavia, cabe destacar que, eventualmente, há casos em que o restante do núcleo familiar não participa das atividades que envolvem a pesca. Ademais, o envolvimento da mulher na pesca comumente pode também se dar no trabalho em peixarias, comércios e/ou indústrias de pescado. Isso pode tanto ser feito por mulheres que historicamente são envolvidas com a pesca como por mulheres que não têm experiência nem família na pesca (Fischer et al., 2013).

As análises empreendidas revelam alguns dos elementos que Diegues \& Arruda (2001) elencam como pertencentes a comunidades tradicionais: dependência do ambiente; importância dada à unidade familiar; reduzida acumulação de capital; tecnologia utilizada relativamente simples e de impacto limitado sobre o meio ambiente; reduzida divisão técnica e social do trabalho, sobressaindo o artesanal; entre outros.

Esses aspectos são responsáveis por demonstrar a história das comunidades pesqueiras, relacionada ao seu modo de vida e produção, que se observa em coevolução com o ambiente, assim como refletem as relações sociais existentes na comunidade. Dessa forma, para compreender a tradicionalidade dessas comunidades, é importante considerar também as seguintes questões: "Como os pescadores chegaram à comunidade pesqueira em que vivem?"; "Desde quando pescam?"; e "Com quem aprenderam a pescar?". A partir destes questionamentos, observam-se aspectos destas comunidades relacionados aos conhecimentos necessários à prática da atividade pesqueira (conhecimento sobre condições do ambiente que influenciam na atividade pesqueira, como a relevância da relação entre ambiente marítimo e lagunar; vazão; condições de 
salinidade; regime de chuvas; conhecimento sobre espécies de peixes; pontos de pesca, etc.), passados de geração em geração, por meio da oralidade; o tempo de envolvimento com a pesca e de moradia nas comunidades pesqueiras, remontando à historicidade e à tradicionalidade da pesca na área de estudo.

Verificou-se que $72 \%$ dos pescadores entrevistados nasceram na comunidade onde residem (Tabela 1), constituindo forte laço e estrutura de pertencimento.

Também se observou que grande parte dos entrevistados pesca: a vida toda (32\%), desde a infância $(66 \%)$ ou desde a adolescência (15\%). O fato é que muitos dos entrevistados destacaram a

TABELA 1 - Percentual de entrevistados em sua relação com a comunidade pesqueira a que pertence atualmente $(n=61)$

\begin{tabular}{ccc}
\hline Como chegou na comunidade? & Freq. & $\begin{array}{c}\text { Freq. } \\
\text { Acum. }\end{array}$ \\
\hline Nasceu na própria comunidade & $72 \%$ & $72 \%$ \\
Veio de outra comunidade do município & $7 \%$ & $79 \%$ \\
Casou com alguém da comunidade & $7 \%$ & $85 \%$ \\
Veio de outro município no estuário & $11 \%$ & $97 \%$ \\
Veio de outra região & $3 \%$ & $100 \%$ \\
Total & $\mathbf{1 0 0} \%$ & \\
\hline
\end{tabular}

FONTE: Elaborado pelos autores. necessidade de estudar, quando passam a ingressar na pesca oficialmente na adolescência, ou entendem que até a adolescência são aprendizes, tornando-se pescadores após os 16 anos. Assim, assumindo tal dinâmica, verificou-se que o ingresso na pesca entre vida toda, infância e adolescência envolve $77 \%$ dos pescadores entrevistados (Tabela 2).

O terceiro elemento é aquele que revela o responsável pelo aprendizado, cuja ênfase é a família nuclear (Tabela 3 ). Os pescadores, contudo, podem ter aprendido a pescar mais de uma pessoa, resultando em um número de respostas superior ao número de entrevistados.

A inserção de tais questões é destacada no relato abaixo:

TABELA 2 - Percentual de pescadores em sua relação com o momento em que iniciaram a atividade pesqueira $(n=66)$

\begin{tabular}{ccc}
\hline Desde quando pesca? & Freq. & $\begin{array}{c}\text { Freq. } \\
\text { Acum. }\end{array}$ \\
\hline A vida toda (0 a 5 anos de idade) & $32 \%$ & $32 \%$ \\
Desde a infância (5 a 14 anos de idade) & $30 \%$ & $62 \%$ \\
Desde a adolescência (14 a 18 anos de idade) & $15 \%$ & $77 \%$ \\
Somente quando adultos (acima de 18 anos) & $23 \%$ & $100 \%$ \\
Total & $\mathbf{1 0 0} \%$ & \\
\hline
\end{tabular}

FONTE: Elaborado pelos autores.

TABELA 3 - Percentual de pescadores em sua relação com quem foi responsável por repassar o aprendizado para iniciação na atividade pesqueira $(n=73)$

\begin{tabular}{cccc}
\hline Categoria & Descrição & Freq. & Freq. Ac. \\
\hline Família Nuclear & Pai, mãe, irmãos, avós, marido/esposa & $71 \%$ & $71 \%$ \\
Família Expandida & Outros familiares (tios, sogros, cunhados) & $12 \%$ & $84 \%$ \\
Outros Pescadores & Outros pescadores (antigos ou não) & $11 \%$ & $95 \%$ \\
Outros & Outros (amigo, compadre) & $5 \%$ & $100 \%$ \\
\hline
\end{tabular}

FONTE: Elaborado pelos autores. 
Nasci aqui, aprendi a pescar com meu pai, todos os meus irmãos são pescadores, meus filhos são pescadores, e acho que a gente vai seguir essa atividade, que já vem lá dos pais, dos avós. (Pescador SLS).

Face ao exposto, em comparação ao aporte teórico utilizado, tais elementos evidenciam que a pesca artesanal no estuário da Lagoa dos Patos se reproduz baseada na tradicionalidade.

\subsection{A captura dos bagres Genidens barbus e Genidens planifrons pelos pescadores artesanais}

Compreendida a tradicionalidade da pesca artesanal no estuário, faz-se necessário entender especificamente como ocorre a pesca do bagre, em sua relação com os demais recursos, e,consequentemente, como se reverbera sobre os pescadores a decisão sobre sua proibição. No estuário da Lagoa dos Patos é permitida apenas a pesca artesanal, cujas embarcações possuem tamanho inferior a 12 metros de comprimento (MMA, 2004). Dentre as pescarias existentes, destaca-se o saquinho/aviãozinho para captura do camarão-rosa; de saco - este utilizado no canal - também para captura do camarão; cordinha para captura do siri; cerco e emalhe para captura de peixes, sendo o emalhe a pescaria com maior predomínio de bagre, em torno de 98,5\% (Kalikoski \&Vasconcellos, 2013; FURG, 2014).

Em relação à composição das pescarias, existem diferenças significativas no que se refere à comunidade e à relevância econômica das espécies capturadas. Conforme Kalikoski \& Vasconcellos (2013), as espécies de água doce se tornam mais abundantes à medida que a pescaria acontece em regiões mais interiores da Lagoa dos Patos, enquan- to espécies marinhas são mais presentes em Rio Grande, São José do Norte, Pelotas e São Lourenço do Sul. Nesse contexto, os autores apontam para essas regiões como importantes no desembarque de camarão-rosa, corvina, tainha, bagre, siri-azul, linguado, peixe-rei e outros.

No que tange aos municípios analisados, as espécies de água doce possuem maior importância para as comunidades pesqueiras situadas na porção superior do estuário, ou seja, São Lourenço do Sul e Pelotas, quando comparadas a Rio Grande e São José do Norte. Traíra, jundiá e cascudo ganham expressividade nos desembarques do Arroio Carahá e do Arroio São Lourenço (São Lourenço do Sul) e na Z-3 (Pelotas), segundo os entrevistados.

Dada a localização das comunidades, seus pescadores são mais vulneráveis aos processos de não salinização da lagoa. Ou seja, conforme dinâmica hidrológica, os pescadores recorrem a diferentes espécies, característica da multiespecificidade da pesca artesanal no estuário. Ao serem questionados, reiteram a importância da salinidade para o sucesso das pescarias: "É quando a água salga que a lagoa vive".

Dentre as espécies capturadas dependentes da salinidade, as três cujo desembarque apresenta descargas significativas, consideradas como de importância relativa primária, são:Micropogonias furnieri (corvina), Mugil platanus (tainha) e Farfantepenaeus paulensis (camarão) (FURG, 2012). Os bagres Genidens barbus, Genidens planifrons e Genidens genidens, Paralichthys orbignyana (linguados) e Odontesthes bonariensis (peixe-rei), dentre outras, constituem espécies de importância relativa secundária (FURG, 2012).

$\mathrm{O}$ início da temporada de pesca, em geral, é em outubro, conforme estabelecido na Instrução 
Normativa Conjunta MMA/SEAP 03/2004 (MMA, 2004) e corroborado pelas entrevistas. Em outubro e nos meses subsequentes, é capturada principalmente a corvina. Após dezembro, perde importância gradativa, até fevereiro, quando se torna proibida. Já a tainha é mais expressiva entre janeiro e maio (FURG, 2012; 2013a; 2013b; 2014; 2015; 2016), mesmo que permitida desde outubro. Em ambas as pescarias, realizadas com rede de emalhe, o bagre é capturado como espécie acessória, conforme salientam os pescadores:

A gente pesca corvina, linguado e vem o bagre junto (Pescador da Z3, Pelotas).

Sempre vem bagre na tainha (...) Cada 10 tainhas vêm 2 bagres, a corvina é a mesma coisa. (Pescador da Z3 Pelotas).

No caso agora, o bagre tá em toda a lagoa, quando tem a tainha eles vão achar com o bagre também, não tem como escapar, com malha 50, aparece de qualquer jeito. É complicado (Pescador da Z3 Pelotas).

Anteriormente a sua proibição, a captura do bagre era permitida nos meses de outubro e novembro e, posteriormente, entre março e maio. De forma geral, há uma grande preocupação dos pescadores em relação à proibição da pesca do bagre, dado que é comum sua captura estar associada a outras pescarias:

A senhora nem tem ideia, quantas toneladas de bagre a gente vai ter que colocar fora, nem tem ideia! Com tanta pobreza nesse nosso país, com a crise que está o nosso país, dizer que a gente vai ter que colocar comida fora, quantas pessoas né? (Pescador de São Lourenço do Sul).

Durante o acompanhamento do desembarque realizado pela FURG, no período de 2012 a 2016, verificou-se que, de um total de 810 descargas da pesca artesanal no estuário, em 577 (71\%) a captura do bagre ocorreu de forma acessória às pescarias de tainha, corvina, linguado ou burriquete (Tabela 4). Em $29 \%$ dos desembarques, o alvo da pescaria foram os bagres.

Os pescadores entrevistados destacam que a relevância do bagre ocorre quando as demais pescarias falham, em especial, devido à lagoa não salgar. Essa condição foi maior no período entre 2013 e 2016, cujo predomínio foi de água doce no estuário ${ }^{5}$.

TABELA 4 - Número total de descargas com emalhe contendo bagre e bagre com outras espécies, no período de janeiro de 2012 a junho de 2016

\begin{tabular}{cccc}
\hline Capturas & NoTotal de Descargas & \% de descarga & Freq. Ac. \\
\hline Bagre/tainha & 285 & $35 \%$ & $35 \%$ \\
Bagre/corvina & 104 & $13 \%$ & $48 \%$ \\
Bagre/linguado & 146 & $18 \%$ & $66 \%$ \\
Bagre/burriquete & 42 & $5 \%$ & $71 \%$ \\
Apenas bagre & 233 & $29 \%$ & $100 \%$ \\
Total & 810 & $100 \%$ & \\
\hline
\end{tabular}

FONTE: Projeto de Estatísticas do Desembarque Pesqueiro - FURG (2012 a 2016).

\footnotetext{
${ }^{5}$ Esta informação está fundamentada nos laudos técnicos elaborados por especialistas da FURG para a safra do camarão em 2013/2014, 2014/2015, 2015/2016 e no acompanhamento dos autores nas reuniões do Fórum.
} 
Algumas falas reportam a dificuldade em relação às sucessivas safras fracassadas e o aumento relativo da importância do bagre no período:

Nós tivemos que dispensar os proeiros e se juntar os três proprietários, porque o outro peixe era muito pouquinho, o peixe que tinha bastante era o bagre, a gente não pode pescar! Tivemos que dispensar eles. Estão desempregados esperando o seguro desemprego que não veio até agora, estão com a luz cortada!(Pescador de São Lourenço do Sul).

O bagre é peixe de duas águas né (salgada/doce), então é um peixe transitório se a água corre do oceano para lagoa, o bagre vem para lagoa, quando a água desvira o bagre sai para fora da lagoa, bagre tem sempre, a gente não trabalha só com o bagre porque na época da liberação a gente trabalha com camarão. O que dá junto com o linguado é o bagre, em pouca quantidade, mas ajuda nas despesas. (Pescador da Z3 Pelotas).

Kalikoski \& Vasconcellos (2013) reportam sobre a importância das espécies secundárias na diminuição da vulnerabilidade social dos pescadores quando de safras fracassadas, intensificadas em eventos climáticos extremos. Na fala dos pescadores, no último ano o bagre tornou-se mais abundante, a princípio, devido à lagoa ter permanecido doce por tanto tempo, fato este que faz com que questionem a proibição da pesca sem uma análise mais substancial sobre sua dependência e sobre a dinâmica do conjunto de pescarias. Neste cenário, de uma pescaria multiespecífica e da ocorrência de bagre nas diversas pescarias, proibir a pesca do bagre é, para os pescadores, inviabilizar a pesca artesanal e a própria existência dos pescadores enquanto população tradicional.

\subsection{A comercialização antes e após a proibição da pesca do bagre}

A maior parte do pescado capturado no estuário é comercializada in naturapara peixarias ou compradores locais e/ou de outras regiões, inclusive do estado de Santa Catarina. Esses compradores atuam na cadeia produtiva comprando o produto dos pescadores e repassando a outros mercados, assim como fornecendo insumos necessários à realização da pescaria e abatendo os valores no momento em que os pescadores entregam o pescado. Estabelece-se, assim, certa dependência do pescador em relação a este ator.

Anteriormente à proibição, a comercialização do bagre acompanhava a das demais espécies capturadas, envolvendo a diversidade de mecanismos presentes na Lagoa. Essas diversas formas de comercialização apresentam maior ou menor relevância a depender da localidade. Em São Lourenço do Sul, por exemplo, antes da proibição o principal comprador para a produção do bagre era a indústria local, a Japesca; em seguida, a Cooperativa dos Pescadores Artesanais Pérola da Lagoa-COOPESCA, e, por último, comerciantes de outras localidades.

Em Rio Grande, a maior parte dessa comercialização era feita para os compradores de Santa Catarina. Segundo justificativa dos pescadores, há escassez de indústrias de pescado nesse município, após a crise do setor vivenciada após a década de 1990. Em seguida vêm os compradores locais e os compradores das ilhas.

Em São José do Norte, o bagre era comercializado para os compradores locais e de outras localidades. Em Pelotas, a maior parte da produção do bagre era comercializada para comerciantes de 
outras localidades e uma parcela menor era vendida para comerciantes locais. Os preços praticados para o bagre e identificados neste estudo variavam entre $\mathrm{R} \$ 2,00$ e R $\$ 3,80^{6}$ o quilo vendido in natura, antes da proibição.

Após a proibição, os canais formais de comercialização foram cessados, em especial junto às agroindústrias e às peixarias formais (salgas ou galpões), mais sujeitas à fiscalização. Quando comercializado, o bagre in natura caiu para $\mathrm{R} \$ 1,00$ / $\mathrm{kg}$. Alguns compradores se arriscam, adquirindo-o e fazendo filés, cujo valor de revenda varia entre $\mathrm{R} \$ 7,00$ e R\$10,00/quilo. Destaca-se que, após a filetagem, o pescado pode ser vendido como outra espécie, dificultando a ação da fiscalização.

Os pescadores se dividem sobre o que fazer. Alguns remetem que lançam os bagres fora, antes do desembarque, dado que o mesmo é capturado junto às demais espécies-alvo. Ao longo das visitas, foram observados bagres mortos na água e nas margens da lagoa. Outros destacam a necessidade de comercializar, frente à baixa produtividade devido ao período de chuvas excessivas, desde 2013. Existindo compradores dispostos a adquirir a produção, arriscam-se à ação da fiscalização e acabam pondo as redes para garantir o sustento familiar.

Também se verifica que, quando da escassez de pescado, devido aos sucessivos fracassos nas safras, bem como da permanência da captura sobre espécies proibidas, a exemplo do bagre, torna-se mais expressiva a comercialização doméstica.

Em síntese, os dados evidenciam que a proibição da pesca do bagre não tem sido uma medida suficiente para garantir a sustentabilidade da espécie. Como a captura incidental é inevitável, ou pescador descarta o bagre, ou o vende clandestinamente por um preço menor que aquele que vigorava anteriormente à proibição. Perde o meio ambiente, pois a proibição pouco contribui na recuperação dos estoques, e perde o pescador artesanal, que, além do risco de ser autuado pela fiscalização, se sujeita ao baixo preço pago pelos compradores.

\section{A gestão da pesca artesanal: bases sobre a decisão em torno do bagre e suas características no estuário da Lagoa dos Patos}

Para compreensão sobre a gestão pesqueira, tendo como perspectiva o debate sobre justiça ambiental, é necessário situar os aspectos técnicos que orientam a decisão de inclusão dos bagres marinhos na lista de espécies ameaçadas de extinção. Assim, dois fatores necessitam de análise: o primeiro deles envolve o conjunto de informações que comumente são consideradas para instrumentalizar a gestão pesqueira, bem como o conjunto de informações que é ignorado, a despeito de a temática conter naturezas inter e multidisciplinar. O segundo é sobre quem participa da decisão, assumindo o que Quintas (2009) aponta sobre o processo assimétrico e conflitivo em torno da decisão ambiental, uma vez que são estes participantes que irão estabelecer quem é sustentável ou não, ou quais os regramentos. Ambos os elementos possibilitam compreender os aspectos que decorrem sobre a natureza justa da decisão.

No Brasil, a gestão pesqueira está estruturada principalmente sob o enfoque biológico (Dias Neto, 2010), sendo as características populacionais e biológicas das espécies consideradas centrais na

${ }^{6}$ Esses valores representam U\$0,60 e U\$1,15, respectivamente, tendo como base o valor do dólar em U\$3,30 à época da pesquisa. 
definição das medidas de gestão. Assim, podem ser estabelecidos regramentos: i) em torno das áreas de pesca, em geral criadouros, cuja medida volta-se ao seu fechamento ou à proibição da pesca; ii) em torno de períodos no ano, ou seja, a proibição da pesca no período de reprodução ou no período de recrutamento dos recursos, conhecidos como defeso; iii) em torno de características biológicas da espécie, o que pode ser a proteção de reprodutores (a exemplo da proibição da captura de fêmeas de caranguejo), ou do tamanho da espécie, cuja intenção é a pescaria ser realizada sob indivíduos de uma determinada idade em que já ocorreu a maturação sexual, o que estabelece decisões em torno do tamanho de malha ou do tamanho e peso dos exemplares, assegurando que os indivíduos capturados já tenham se reproduzido ao menos uma vez; iv) sobre as características das pescarias, o que pode estabelecer cotas de captura ou a proibição de equipamentos mais eficazes ou que atuam sob maior diversidade de espécies, denominados de menos seletivos (Dias Neto, 2010).

A avaliação de estoques - que envolve o conhecimento sobre os principais parâmetros biológicos da espécie (idade de reprodução, longevidade, mortalidade natural e por pesca, recrutamento) - é o principal mecanismo para estabelecer uma quantidade ideal a ser pescada (Dias Neto, 2010). Para inclusão das espécies na IUCN - que culminaram na Portaria MMA 445/2014 -, foram realizadas oficinas com especialistas que, com base em dados de captura, indicam níveis de sobreexplotação. Quedas de captura abruptas indicam que a "pressão pesqueira" é muito alta, sendo correlacionadas ao nível de ameaça das espécies, o que inclui sua inserção na Lista de Espécies Ameaçadas de Extinção, resultando em uma proibição automática sobre a atividade pesqueira (Pinheiro et al., 2015).
Neste sentido, as espécies de bagre situadas na lista são encontradas ao longo da zona costeira, tanto no ambiente estuarino como no ambiente marinho. Via de regra, são capturadas pelas frotas artesanal e industrial, que exercem pressões distintas, em fases diferenciadas do estágio de vida das populações (Haimovici, 1997).

Diegues (1983) caracteriza a organização socioprodutiva de pescadores artesanais e industriais, destacando a maior capacidade da frota industrial na captura e a maior divisão de trabalho na embarcação. Em especial, o fato de a pesca industrial se caracterizar por uma atividade que visa à acumulação do lucro, exercendo forte pressão sobre os recursos ambientais e tendo pouca dependência da integridade dos mesmos, dado que, ao se exaurir um estoque, o setor se destina a outro e assim sucessivamente. Outra característica relevante da pesca industrial é a maior autonomia em dias/mar de suas embarcações, cujo tamanho e instrumentos de navegação possibilitam percorrer maiores áreas e desembarcar em distintos portos de diferentes Estados. E, por último, não é possível ignorar que historicamente a pesca industrial conta com incentivos do estado, incluindo a subvenção ao óleo diesel, o que aumenta ainda mais a "pressão" sobre o meio ambiente (Abdallah \& Sumaila, 2007).

Em relação ao bagre, no estado do Rio Grande do Sul, as comunidades pesqueiras artesanais atuam sobre os estoques no ambiente estuarino e próximos à costa. Já a frota industrial atua na porção marítima.

A proibição estabelecida pela Portaria 445/2014 resultou na restrição em todo o território nacional, enquanto a Lei Estadual 51.797/2014 restringiu-a no estado do Rio Grande do Sul. Entretanto, a maior pressão do setor industrial sobre a lista culminou na suspensão da Portaria 445/2014 (Pinheiro et al., 
2015), recaindo apenas aos pescadores artesanais dos estuários do Rio Grande do Sul a proibição, dado que a lei estadual permanece em vigor.

Os elementos apropriados pela gestão pesqueira para tomada de decisão são centrados nas características das espécies. Ignoram as características dos atores que exercem pressão. Sob o argumento da sustentabilidade, estabelecem uma medida incapaz de restringir a pressão sobre a pesca para aqueles agentes econômicos que exercem maior pressão sobre os estoques. Acselrad (2004) aponta os elementos argumentativos em torno da sustentabilidade e que culminam em processos de expropriação do direito de acesso de determinados grupos, neste caso, os pescadores artesanais.

$\mathrm{O}$ segundo elemento que se faz necessário compreender é sobre o processo decisório, ou seja, em relação a quem participa da decisão sobre o meio ambiente. Na gestão pesqueira, este pode ser centralizado pelo Estado ou compartilhado junto aos atores sociais que são afetados pelas medidas, neste último caso caracterizado pelo que se denomina gestão pesqueira compartilhada (Berkes et al., 2006).

Segundo Pomeroy (1996), a gestão compartilhada da pesca é definida como uma parceria dinâmica, utilizando as capacidades e interesses dos pescadores e das comunidades locais, complementados pela capacidade do Estado em prover políticas públicas e legislação específica. No Brasil, tais processos coincidem com o movimento de redemocratização política do país, sendo exemplos, os Fóruns de Pesca e as Reservas Extrativistas Marinhas.

O histórico da gestão pesqueira compartilhada na Lagoa dos Patos remete à década de 1990, quando em 1996, a partir da constatação da precarização da pesca artesanal devido à diminuição da produti- vidade pesqueira, foi criado o Fórum da Lagoa dos Patos. Seu surgimento envolve o esforço inicial do Conselho da Pastoral do Pescador, do Centro de Pesquisa e Gestão dos Recursos Pesqueiros Lagunares e Estuarinos - CEPERG, na época, vinculado ao IBAMA, e das Colônias de Pescadores. Seu intuito era romper com o padrão centralizador de gestão, abrindo espaço para uma forma mais participativa de tomada de decisão (Kalikoski, 2002).

O Fórum tem como finalidades, ainda, a defesa, a preservação e a conservação do meio ambiente no setor pesqueiro, bem como a promoção do desenvolvimento econômico e social e o combate à pobreza. Suas conquistas remetem à definição de normativas específicas. Ainda que persistam alguns conflitos antigos decorrentes de uma visão de gestão pesqueira centralizada no Estado, o Fórum promoveu a discussão de questões relevantes, resultando na edição de normas que trouxeram a gestão pesqueira mais próxima para a realidade dos pescadores artesanais do estuário. Duas Portarias e uma Instrução Normativa Conjunta foram concebidas a partir das discussões efetuadas em seu âmbito, adequadas às necessidades locais: a Portaria IBAMA n ${ }^{\circ} 80 / 2003$ proibiu a pesca de cerco (traineiras) na região de acesso ao estuário (IBAMA, 2003), enquanto a Portaria do IBAMA 171/98 (IBAMA, 1998) e, posteriormente, a Instrução Normativa Conjunta MMA/SEAP 03/2004 especificam com clareza os limites físicos do estuário e quem legalmente pode exercer a atividade pesqueira restringindo-a aos pescadores moradores dos municípios adjacentes à Lagoa e orientando uma iniciativa de licenciamento ambiental da pesca, que se constitui no principal mecanismo de regulação da atividade e de controle do esforço de pesca (MMA, 2004). 
O licenciamento ambiental da pesca artesanal, que vem sendo implementado desde o ano de 1998, estabelece que: i) a atividade de pesca no Estuário da Lagoa dos Patos está condicionada a licenças de pesca, fornecidas anualmente pelo IBAMA, aos pescadores devidamente legalizados mediante requerimento dos interessados; ii) as licenças de pesca devem ser renovadas anualmente, no período de $1^{\circ}$ de junho a 30 de agosto; iii) o pescador licenciado é obrigado a entregar as planilhas de controle preenchidas (mapas de bordo) ao IBAMA, anualmente; iv) a autorização para a pesca é individual e cada pescador somente pode ser portador de uma licença, independentemente do número de embarcações registradas em seu nome; v) os pedidos de licenças somente são concedidos após ser ouvido o Fórum da Lagoa dos Patos, onde os representantes das comunidades pesqueiras exercem funções consultiva e cooperativa às ações do IBAMA (MMA, 2004).

Não obstante, com a promulgação do Decreto 6.981, de 13 de outubro de 2009 (Brasil, 2009), a gestão compartilhada da pesca no Brasil se deslocou da relação Estado-sociedade - oriunda de um desdobramento dos movimentos sociais que almejavam, no processo de redemocratização, maior participação da sociedade nas decisões relacionadas às políticas públicas ${ }^{7}$ - para uma relação entre dois entes do Estado, envolvendo o "compartilhamento" da gestão entre Ministério da Pesca e Aquicultura MPA - e Ministério do Meio Ambiente - MMA. A partir daí, a participação da sociedade e dos representantes dos pescadores vai sendo gradativamente ignorada.
Demarcam este período, em âmbito nacional, um viés produtivista da atividade pesqueira, caracterizado principalmente por maiores investimentos à aquicultura e à indústria pesqueira, cujo pescado é destinado ao mercado internacional, e conflitos ambientais oriundos de um modelo neodesenvolvimentista (Azevedo \& Pierri, 2014).

Por meio da participação nas reuniões do Fórum da Lagoa dos Patos e de consulta em suas atas, verifica-se que, desde então, há um esvaziamento das entidades que representam os governos federal e estadual. A presença de ambos, que ocorria até meados dos anos 2000 de forma sistemática, torna-se pontual, associada a pautas específicas quando de interesse. Exemplo é a revisão da Portaria Conjunta MMA/SEAP 03/2004, que foi proposta pelos pescadores e demais entidades integrantes do Fórum em 2014 e até o momento não obteve retorno. De maneira análoga, não houve consulta ou participação ao Fórum sobre as normativas federal e estadual que versam sobre a proibição do bagre, tendo sido as mesmas elaboradas por especialistas sem qualquer envolvimento das comunidades tradicionais que delas dependem (Pinheiro et al., 2015).

De forma geral, ignora-se o acúmulo e a experiência empreendida no escopo desta instância, ainda que esta envolva uma ampla participação dos(as) pescadores(as) artesanais que se reúnem mensalmente. Por outro lado, pescadores, suas lideranças e entidades apoiadoras têm se mobilizado de forma a questionar a medida e explicitar a precarização e a vulnerabilização que a mesma tem gerado às comunidades pesqueiras do estuário.

\footnotetext{
${ }^{7}$ Para compreender os dois projetos de país em torno da participação, que culminam em uma confluência perversa, sugere-se a leitura de Dagnino (2004). A autora retrata como a concepção de participação demandada pelos movimentos sociais no processo de redemocratização se opõe ao projeto neoliberal, cuja intenção é desresponsabilizar o Estado e ampliar as forças do mercado. Discorre não apenas como participação é um conceito polissêmico, mas permanentemente em disputa.
} 
Assim, a proibição da pesca do bagre, além de ser uma decisão arbitrária do Estado, nega os princípios de participação social nas decisões sobre o meio ambiente, infringindo as normativas analisadas anteriormente, que versam sobre a obrigatoriedade de consulta às comunidades tradicionais afetadas pela decisão.

\section{Considerações finais}

No caso estudado, cuja decisão sobre a inclusão das espécies de bagres Genidens barbus e Genidens planifrons na lista de espécie ameaçadas de extinção recai apenas sobre os pescadores artesanais do Estado do Rio Grande do Sul, verificou-se, por meio da análise sobre as comunidades pesqueiras do estuário da Lagoa dos Patos, que se trata de um mecanismo que gera injustiça ambiental.

Tal medida possui uma desigualdade estrutural, reverberando sobre os pescadores artesanais do Estado do Rio Grande do Sul tal decisão. Em relação aos pescadores artesanais do estuário da Lagoa dos Patos, comunidades tradicionais de pesca, verificou-se que a medida ignora direitos estabelecidos pela legislação, dentre eles o de garantir a participação destas comunidades nos processos decisórios que se relacionam à sua manutenção, como no âmbito da pesca artesanal. Tanto a Portaria 445/2014 como a Lei Estadual $n^{\circ} 51.797 / 2014$ desconsideram a necessidade de consulta e construção coletiva junto aos pescadores artesanais, ferindo ambas os direitos legais assegurados aos pescadores artesanais.

A negligência perversa dos órgãos estaduais vinculados à discussão pesqueira corrobora ainda o quadro de injustiça ambiental aplicada aos pescadores artesanais do estuário da Lagoa dos Patos. A despeito da pressão dos pescadores, as discussões para elaborar o plano de manejo para o bagre estão em tramitação desde meados de 2016 e até o momento não obtiveram encaminhamento.

Para além do atendimento às normativas quando do debate sobre sustentabilidade e gestão dos recursos naturais -, torna-se relevante a compreensão sobre como os diferentes grupos sociais se apropriam dos recursos ambientais. A ausência de um recorte de classe na gestão pesqueira resulta em um processo discriminatório, cujos pescadores artesanais, dependentes da integridade ambiental e dos recursos necessários a sua reprodução social, são aqueles mais afetados quando da decisão sobre a proibição da pesca do bagre. Enquanto isso, outros atores, a exemplo da pesca industrial, que atuam em uma lógica de expropriação da natureza, garantem a manutenção dos lucros oriundos de suas pescarias.

Nesse cenário, é preciso superar a dicotomia sociedade-ambiente, comumente colocada como elemento norteador da gestão pesqueira no Brasil e abordá-la sob a perspectiva de promoção da justiça ambiental.

\section{Agradecimentos}

Os autores agradecem aos pescadores artesanais que participaram das entrevistas, às acadêmicas Maranize Grellert e Mônica Guedes que contribuíram com a coleta de dados e a Tecnóloga em Gestão Ambiental Andrine Longaray pela elaboração do mapa da área de estudo. Também agradecemos à Pro-Reitoria de Extensão e Cultura - PROEXC da Universidade Federal do Rio Grande (FURG) pelo financiamento da pesquisa. 


\section{Referências}

Abdallah, P. R.; Sumaila, U. R. An historical account of Brazilian public policy on fisheries subsidies. Marine Policy, 31, 444-450,2007.

Acselrad, H. Justiça Ambiental - ação coletiva e estratégias argumentativas. In: Acselrad, H.; Herculano, S.; Pádua, J. A. (Orgs.) Justiça Ambiental e Cidadania. Niterói/RJ: Editora UFF, 2004. p. 23-40.

Arruda, R. Populações tradicionais e a proteção de recursos naturais em unidades de conservação. Ambiente \& Sociedade, II(2), 1989. Disponível em: <http://www.scielo.br/ $\mathrm{pdf} / \mathrm{asoc} / \mathrm{n} 5 / \mathrm{n} 5 \mathrm{a} 07 . \mathrm{pdf}>$

Azevedo, N. T.; Pierri, N. A política pesqueira no Brasil (2003-2011): a escolha pelo crescimento produtivo e o lugar da pesca artesanal. Desenvolvimento e Meio Ambiente,32, 61-80, 2014. doi: 10.5380/dma.v32i 0.35547

Berkes, F.; Mahon, R.; McConney, P.; Pollnac, R.; Pomeroy, R. Gestão da pesca de pequena escala: diretrizes e métodos alternativos. Kalikoski, D. C. (Org. versão português); Costa, R. (Trad.). Rio Grande: FURG, 2006.

Brasil. Constituição da República Federativa do Brasil, de 5 de outubro de 1988. 11. ed. São Paulo: Atlas, 1998.

Brasil. Decreto n. ${ }^{\circ}$ 5.051, de 19 de abril de 2004. Promulga a Convenção 169 da Organização Internacional do Trabalho - OIT sobre Povos Indígenas e Tribais. DOU de 20/12/2004. Disponível em: <http://www.planalto.gov. br/ccivil_03/_ato2004-2006/2004/decreto/d5051.htm>. Acesso em: ago. 2017.

Brasil. Decreto $n{ }^{\circ}$ 6.040, de 7 de fevereiro de 2007. DOU de 08/02/2007. Disponível em: <http://www.planalto.gov. br/ccivil_03/_ato2007-2010/2007/decreto/d6040.htm>. Acesso em: ago. 2017.

Brasil. Decreto $n$. $^{\circ} 6.981$, de 13 de outubro de 2009. Dispõe sobre a atuação conjunta dos Ministérios da Pesca e Aquicultura e do Meio Ambiente nos aspectos relacionados ao uso sustentável dos recursos pesqueiros. Brasília: DOU 14/10/2009. Disponível em: <http://www.planalto.gov. br/ccivil_03/_Ato2007-2010/2009/Decreto/D6981.htm>. Acesso em: ago. 2017.
Dagnino, E. Sociedade civil, participação e cidadania: de que estamos falando? In: Mato, D. (Org.). Políticas de Ciudadanía y Sociedad Civil en tiempos de globalización. Caracas: FACES, Universidad Central de Venezuela, 2004. p. 95-110.

Dias Neto, J. Gestão do uso dos recursos pesqueiros no Brasil. Brasília: Editora IBAMA, 2010.

Diegues, A.C. Pescadores, camponeses e trabalhadores do mar. São Paulo/SP: Ática, 1983.

Diegues, A.C.; Arruda, R. S. V. (Orgs.). Saberes tradicionais e biodiversidade no Brasil. Brasília: MMA; São Paulo: USP, 2001.

FAO - Food and Agriculture Organization of the United Nations. The State of World Fisheries and Aquaculture Opportunities and challenges. Roma. 2014. Disponível em: <http://www.fao.org/3/a-i3720e.pdf >. Acesso em: ago. 2017.

Fischer, J.; Gonçalves, C. H.; Walter, T. O envolvimento das mulheres na safra do camarão no estuário da Lagoa dos Patos/RS: a importância da análise da cadeia produtiva do pescado no contexto da Gestão Ambiental. In: Anais do IV Congresso Brasileiro de Gestão Ambiental. Salvador/ BA - 25 a 28/11/2013.

Fórum da Lagoa dos Patos. Estatuto do Fórum da Lagoa dos Patos. Rio Grande, 1998.

Fórum da Lagoa dos Patos. Ata 001/2016: Reunião Ordinária do Fórum da Lagoa dos Patos - São José do Norte. São José do Norte, 2016a. Disponível em: <http://www. forumlagoadospatos.furg.br/index.php/atas-das-reuniões. html>. Acesso em: ago. 2017.

Fórum da Lagoa dos Patos. Ata 003/2016: Reunião Extraordinária do Fórum da Lagoa dos Patos - Rio Grande. Rio Grande, 2016b. Disponível em: $<$ http://www.forumlagoadospatos.furg.br/index.php/atas-das-reuniões.html $>$. Acesso em: ago. 2017.

Fórum da Lagoa dos Patos. Ata 006/2016: Reunião Extraordinária do Fórum da Lagoa dos Patos - Pelotas. Pelotas, 2016c. Disponível em: <http://www.forumlagoadospatos. furg.br/index.php/atas-das-reuniões.html>. Acesso em: ago. 2017. 
Fórum da Lagoa dos Patos. Ata 009/2016: Reunião Ordinária do Fórum da Lagoa dos Patos - Pelotas.Pelotas, 2016d. Disponível em: <http://www.forumlagoadospatos.furg.br/ index.php/atas-das-reuniões.html>. Acesso em: ago. 2017.

Freitas, C. M. de. Ciência para a sustentabilidade e a justiça ambiental.In: Acselrad, H.; Herculano, S.; Pádua, J. A. (Orgs.). Justiça Ambiental e Cidadania. 2. ed. Rio de Janeiro, 2004. p. 141-158.

FURG - Universidade Federal do Rio Grande. Boletim Estatístico da Pesca Marinha e Estuarina do Sul do Rio Grande do Sul-Ano 2012. Projeto de Estatísticas de Desembarque Pesqueiro da Região Sul do Rio Grande do Sul e Região Oceânica adjacente. Rio Grande: Universidade Federal do Rio Grande, Laboratório de Estatística Ambiental, 2012. Disponível em: <http://www.imef.furg.br/images/stories/ documentos/boletim\%20furg\%20\%202012.pdf>. Acesso em: ago. 2017.

FURG - Universidade Federal do Rio Grande.Boletim Estatístico da Pesca Marinha e Estuarina do Sul do Rio Grande do Sul - Ano 2013 (1 ${ }^{\circ}$ semestre).Projeto de Estatísticas de Desembarque Pesqueiro da Região Sul do Rio Grande do Sul e Região Oceânica adjacente. Rio Grande, Universidade Federal do Rio Grande, Laboratório de Estatística Ambiental, 2013. Disponível em: <http://www.imef.furg. br/images/stories/documentos/boletim\%20furg\%202013-1. pdf $>$. Acesso em: ago. 2017.

FURG- Universidade Federal do Rio Grande.Boletim Estatístico da Pesca Marinha e Estuarina do Sul do Rio Grande do Sul - Ano 2013 ( $2^{\circ}$ semestre). Projeto de Estatísticas de Desembarque Pesqueiro da Região Sul do Rio Grande do Sul e Região Oceânica adjacente. Rio Grande, Universidade Federal do Rio Grande, Laboratório de Estatística Ambiental, 2013. Disponível em: <<http://www.imef.furg. br/images/stories/documentos/boletim\%20furg\%202013-2. pdf>. Acesso em: ago. 2017.

FURG- Universidade Federal do Rio Grande. Boletim Estatístico da Pesca Marinha e Estuarina do Sul do Rio Grande do Sul - 2014.Projeto de Estatísticas de Desembarque Pesqueiro da Região Sul do Rio Grande do Sul e Região Oceânica adjacente. Rio Grande, Universidade Federal do Rio Grande, Laboratório de Estatística Ambiental, 2014. Disponível em: <http://www.imef.furg.br/images/stories/ documentos/boletim\%20furg\%202014.pdf $>$. Acesso em: ago. 2017.

FURG- Universidade Federal do Rio Grande. Boletim Estatístico da Pesca Marinha e Estuarina do Sul do Rio Grande do Sul - 2015. Projeto de Estatísticas de Desembarque Pesqueiro da Região Sul do Rio Grande do Sul e Região Oceânica adjacente. Rio Grande, Universidade Federal do Rio Grande, Laboratório de Estatística Ambiental, 2015. Disponível em: <http://www.imef.furg.br/images/stories/ documentos/boletim\%20furg\%202015.pdf $>$. Acesso em: ago. 2017.

FURG- Universidade Federal do Rio Grande. Boletim Estatístico da Pesca Marinha e Estuarina do Sul do Rio Grande do Sul - 2016. Projeto de Estatísticas de Desembarque Pesqueiro da Região Sul do Rio Grande do Sul e Região Oceânica adjacente. Rio Grande, Universidade Federal do Rio Grande, Laboratório de Estatística Ambiental, 2016. Disponível em:

$<$ http://www.imef.furg.br/images/stories/documentos/Boletim-Estatstica-Pesqueira-2016-.pdf

Haimovici, M. Recursos pesqueiros demersais da região sul. Subsídios para o levantamento do estado da arte dos recursos vivos marinhos do Brasil - Programa Revizee, 1997.

Herculano, S. O clamor por Justiça Ambiental e contra o Racismo Ambiental. Revista InterfaceHS, 3(1), Artigo 2, 2008. 20p.

IBAMA - Instituto Brasileiro do Meio Ambiente e dos Recursos Naturais Renováveis. Portaria $n^{\circ} 171$, de 22 de dezembro de 1998. Dispõe sobre a atividade de pesca no Estuário da Lagoa dos Patos/RS. Brasília: DOU de 23/12/1998. Disponível em: <http://www.icmbio.gov.br/ cepsul/legislacao/portaria/270-1998.html>. Acesso em: ago. 2017.

IBAMA - Instituto Brasileiro do Meio Ambiente e dos Recursos Naturais Renováveis. Portaria $n^{\circ} 80 / 03-N$, de 11 de dezembro de 2003. Dispõe sobre a proibição da pesca na modalidade de cerco na região oceânica de acesso ao Estuário da Lagoa dos Patos. Brasília, 11 dez. 2003. Disponível em: <http://www.icmbio.gov.br/cepsul/legislacao/ portaria/275-2003.html>. Acesso em: ago. 2017.

IBAMA - Instituto Brasileiro do Meio Ambiente e dos 
Recursos Naturais Renováveis. Portaria $n^{\circ} 445$. Brasília: DOU de 17/12/2014. Disponível em: <http://www.icmbio. gov.br/cepsul/images/stories/legislacao/Portaria/2014/p mma_445_2014_lista_peixes_ameaçados_extinção.pdf $>$. Acessoem: 30 ago. 2017.

Kalikoski, D. C. The Forum of the Patos Lagoon: An analysis of co-management arrangement for conservation of coastal resources in southern Brazil.Canadá, Tese (Doutorado) - Program of Resource Management and Environmental Studies/University of British Columbia, 2002.

Kalikoski, D. C.; Vasconcellos, M. Estudo das condições técnicas, econômicas e ambientais da pesca de pequena escala no estuário da Lagoa dos Patos, Brasil: uma metodologia de avaliação. FAO Fisheries and Aquaculture. Circular n. 1075. Rome: FAO, 2013.

Layrargues, P. P. Educação Ambiental com compromisso social: o desafio da superação das desigualdades. In: Loureiro, C. F. B.; Layrargues, P. P.; Castro, R. S de. (Orgs.). Repensar a educação ambiental: um olhar crítico. São Paulo: Cortez, 2009. p. 11-31. ISBN 978-85-249-1502-4.

Leff, E. Racionalidade ambiental: a reapropriação social da natureza. Cabral, L. C. (Trad.). Rio de Janeiro: Civilização Brasileira, 2006.

Martínez Alier, J. O ecologismo dos pobres:conflitos ambientais e linguagens de valoração. Waldman, M. (Trad.). 1. ed., $2^{\mathrm{a}}$ reimpr. São Paulo: Contexto, 2011.

Minayo, M. C. S. O desafio do conhecimento: pesquisa qualitativa em saúde.13.ed. São Paulo: Hucitec, 2013. 407 p.

Minayo, M. C. de S.; Assis, S. G. de; Souza, E. R. de. Avaliação por triangulação de métodos: abordagem de programas sociais. Rio de Janeiro: Editora Fiocruz, 2005.

MMA - Ministério do Meio Ambiente. Panorama da Conservação dos Ecossistemas Costeiros e Marinhos no Brasil. Brasília/DF: MMA/SBF/GBA, 2010, 148p. ISBN 978-85-7738-142-5.

MMA - Ministério do Meio Ambiente. Instrução Normativa Conjunta $n^{\circ} 3$, de 9 de fevereiro de 2004. Dispõe sobre a atividade de pesca no Estuário da Lagoa dos Patos no Estado do Rio Grande do Sul. Brasília: DOU de 09/02/2004. Disponível em: <http://www.icmbio.gov.br/cepsul/legislacao/ins- trucao-normativa/342-2004.html>. Acesso em: ago. 2017.

Pinheiro, A. A. M.; Alves, B. M. C.; Boos, H.; Dario, F. di; Figueiredo, A. C.; Frédou, L. F.; Lessa, P. T. R.; Mincarone, M. M.; Polaz, N. M.C.; Reis, E. R.; Rocha, A. L.; Santos, A. R.; Santos, B. S.; Vianna, M.; Vieira, F. Conservar a fauna aquática para garantir a produção pesqueira. Ciência e Cultura, 67(3), 56-59, 2015. doi: 10.21800/2317$66602015000300017>$.

Pomeroy, R. Analysis of fisheries co-management arrangements: a research framework. Prepared by Fisheries Co-Management Project Core Staff at the International Center for Living Aquatic Resources Management (ICLARM) and North Sea Center (NSC). 1996.

Porto-Gonçalves, C. W.; Leff, E. Political Ecology in Latin America: the Social Re-Appropriation of Nature, the Reinvention of Territories and the Construction of an Environmental Rationality. Desenvolvimento e Meio Ambiente, 35, 65-88, 2015. doi: 10.5380/dma.v35i0.43543

Quintas J. S. Educação no processo de gestão ambiental pública: a construção do ato pedagógico. In: Loureiro, C. F. B.; Layrargues, P. P.; Casto, R. S. (Org.). Repensar a Educação Ambiental: um olhar crítico. São Paulo: Cortez, 2009. p. 33-80.

Rio Grande do Sul (Estado). Decreto $n^{\circ} 51.797$, de 8 de setembro de 2014. Declara as Espécies da Fauna Silvestre Ameaçadas de Extinção no Estado do Rio Grande do Sul. DOE n. ${ }^{\circ} 173$, de 09/09/2014. Disponível em: <http://www. al.rs.gov.br/legis/>. Acesso em: ago. 2017.

Rosa, N. B. G. Análise crítica do processo de licenciamento ambiental daPesca Artesanal no Estuário da Lagoa dos Patos - RS. Rio Grande, Dissertação (Mestrado) - Programa de Pós-Graduação em Gerenciamento Costeiro, FURG, 2016.

Silva. L. G. Os pescadores na história do Brasil. Volume 1. Colônia e Império. Comissão Pastoral do Pescador. Luis Geraldo Silva (Coord.). Recife-PE, 1988.

SEMA. Secretaria do Ambiente e Desenvolvimento Sustentável. Portaria SEMAn ${ }^{\circ}$ 94/2016. Designa os representantes que integrarão o Grupo de Trabalho instituído pelo Decreto Estadual 53.123 de 05 de Junho de 2016. Diário Oficial do Estado do Rio Grande do Sul de 19 de Agosto de 2016. Disponível em: <http://www.sema.rs.gov.br/upload/arqui- 
vos/201610/24180428-2016-port-sema-n-94-designa-repre- Thiollent, M. T. Metodologia da pesquisa-ação. São Paulo: sentantes-gt-instituido-pelo-dec-est-53123-2016-dia-19-08. Cortez, 2007.

pdf. Acesso em 16 de novembro de 2017. 